\title{
Gambaran Tingkat Pengetahuan Perawat Tentang Code Blue System di RSUP Prof. Dr. R. D. Kandou Manado
}

\author{
${ }^{1}$ Randi B. Dame \\ ${ }^{2}$ Lucky T. Kumaat \\ ${ }^{2}$ Mordekhai L. Laihad
}

\author{
${ }^{1}$ Program Studi Pendidikan Dokter Fakultas Kedokteran Universitas Sam Ratulangi Manado \\ ${ }^{2}$ Bagian Anestesiologi dan Terapi Intensif Fakultas Kedokteran Universitas Sam Ratulangi - \\ RSUP Prof. Dr. R. D. Kandou Manado \\ Email: damerandi@gmail.com
}

\begin{abstract}
Code blue system is an emergency system consisting of a code blue team that provides immediate relief to all patients with emergencies during respiratory arrest and/or cardiac arrest. The application of code blue aims to reduce mortality and increase the rate of return of spontaneous circulation (ROSC). To achieve the goal of implementing the blue system code, nurses as the code blue local team must have good level of knowledge and understanding of the code blue system. This study was aimed to determine the profile of nurses' knowledge about the code blue system at Prof. Dr. R. D. Kandou Hospital Manado. This was a descriptive study with a cross sectional design. Data of demography and measurement were obtained by using questionnaires. Respondents were 91 nurses who were in charge in medical ward of Prof. Dr. R. D. Kandou Hospital Manado. The results showed that 27 nurses (29.67\%) had high level category of knowledge about code blue systems; 23 nurses (25.28\%) had fairly high level category; 24 nurses (26.37\%) had low level category, and 17 $(18.68 \%)$ nurses had very low level category. Conclusion: The majority of nurses at Prof. Dr. R. D. Kandou Hospital Manado had high level category of knowledge about the code blue system.
\end{abstract}

Keywords: knowledge level, code blue system, nurse

\begin{abstract}
Abstrak: Code blue system adalah sistem kegawatdaruratan yang terdiri dari tim code blue yang memberikan pertolongan segera pada semua pasien dengan kegawatdaruratan saat henti napas dan atau henti jantung. Penerapan code blue bertujuan untuk mengurangi angka mortalitas serta meningkatkan angka return of spontaneous circulation (ROSC) atau kembalinya sirkulasi spontan. Untuk mencapai tujuan dari penerapan code blue system, perawat sebagai salah satu responden tim code blue lokal harus memiliki tingkat pengetahuan dan pemahaman yang baik tentang code blue system. Penelitian ini bertujuan untuk mengetahui gambaran tingkat pengetahuan perawat tentang code blue system di RSUP Prof. Dr. R. D. Kandou Manado. Jenis penelitian ialah deskriptif dengan desain potong lintang. Data demografi dan hasil pengukuran menggunakan alat ukur kuesioner. Responden penelitian ialah 91 perawat yang bertugas di irina-irina RSUP Prof. Dr. R. D. Kandou Manado. Hasil penelitian mendapatkan sebanyak 27 perawat $(29,67 \%)$ mempunyai tingkat pengetahuan tentang code blue system dengan kategori tinggi; 23 perawat $(25,28 \%)$ dengan kategori cukup tinggi; 24 perawat $(26,37 \%)$ dengan kategori rendah; dan 17 peerawat (18,68\%) dengan kategori sangat rendah. Simpulan: Mayoritas perawat di RSUP Prof. Dr. R. D. Kandou Manado mempunyai tingkat pengetahuan tentang code blue system pada kategori tinggi

Kata kunci: tingkat pengetahuan, code blue system, perawat
\end{abstract}

Rumah sakit memiliki peranan penting dalam menyediakan pelayanan yang optimal untuk semua pasien dengan kasus henti jantung, terlepas dari lokasi pasien mengalami henti jantung, di rumah sakit (inhospital cardiac arrest) atau di luar rumah 
sakit (out-of hospital cardiac arrest). Tingkat kelangsungan hidup dan luaran yang baik bervariasi antara in-hospital cardiac arrest (IHCA) dan out-of-hospital cardiac arrest (OHCA). ${ }^{1}$ Menurut data dari American Heart Association (AHA), di Amerika terdapat lebih dari 200.000 kasus IHCA per tahunnya, dengan tingkat kelangsungan hidup bervariasi tiap rumah sakit, mulai dari 0 sampai $36,2 \%$. $^{2,3}$ Prevalensi henti jantung menurut Perhimpunan Dokter Spesialis Kardiovaskular Indonesia (PERKI) berkisar 10 dari 100.000 orang normal yang berusia dibawah 35 tahun dan per tahunnya mencapai sekitar 300.000-350.000 kejadian. ${ }^{4}$ Henti jantung adalah kasus kegawatdaruratan yang harus mendapatkan penanganan yang tepat dan segera dari medis atau masyarakat umum yang terlatih. ${ }^{5}$

Code blue system adalah sistem emergensi yang terdiri atas tim code blue yang memberikan pertolongan segera pada semua pasien dengan kegawatdaruratan saat henti napas dan atau henti jantung. ${ }^{6}$ Henti jantung adalah berhentinya fungsi jantung secara tiba-tiba pada seseorang yang telah atau belum diketahui menderita penyakit jantung. ${ }^{7}$ Penanganan khusus, seperti bantuan hidup dasar dan juga bantuan hidup lanjut yang efektif diperlukan untuk menangani kasus henti jantung, karena kematian otak dan kematian permanen terjadi dalam jangka waktu 8 sampai 10 menit setelah seseorang mengalami henti jantung. ${ }^{5,8}$ Berdasarkan kajian tersebut, aktivasi code blue system yang ideal harus mampu memfasilitasi resusitasi pada pasien dengan kegawatdaruratan medis dan kondisi henti jantung dengan respon yang adekuat. ${ }^{8}$

Penerapan code blue system bertujuan untuk mengurangi angka mortalitas serta meningkatkan angka return of spontaneous circulation (ROSC) atau kembalinya sirkulasi spontan. ${ }^{6}$ Penanganan henti jantung yang tertunda berhubungan dengan rendahnya angka harapan hidup dari korban henti jantung. Untuk mencapai tujuan dari penerapan code blue system diperlukan pengenalan awal dari kasus henti jantung, dalam hal ini pengetahuan akan code blue system dan bantuan hidup dasar. ${ }^{9}$ Pembagian tim code blue di RSUP Prof. Dr. R. D Kandou terdiri atas tim pusat, area, dan lokal. ${ }^{6}$ Tim lokal code blue terdiri dari dokter, perawat, atau karyawan sebagai penemu pertama korban henti jantung. ${ }^{6}$ Perawat yang tergolong dalam tim code blue lokal merupakan salah satu pengguna utama pengaktifan sistem kegawatdaruratan dan menjadi responden pertama (tim code blue lokal) dalam melakukan resusitasi. ${ }^{10}$

Keahlian seorang perawat, bergantung pada tingkat pengetahuan dan ketrampilannya. Sebagai salah satu responden (tim code blue lokal), tidak hanya mengenali pasien yang memerlukan tindakan segera tapi seorang perawat juga dituntut untuk melakukan intervensi awal dalam menangani kasus. ${ }^{11}$

Studi yang dilakukan oleh Sahin et $\mathrm{al}^{11}$ yang mengevaluasi code blue di rumah sakit anak Dr. Behcet Uz Turkey mendapatkan bahwa kesadaran dan efektivitas dari code blue meningkat setelah diberikannya edukasi pada setiap staf rumah sakit. Berdasarkan kajian-kajian tersebut, penge-tahuan dan pemahaman yang baik tentang code blue system harus dimiliki setiap perawat yang bertugas di rumah sakit. Penelitian terkait dengan code blue system, sebelumnya belum pernah dilakukan di RSUP Prof. Dr. R. D. Kandou. Penelitian ini bertujuan untuk mengetahui gambaran tingkat pengetahuan perawat tentang code blue system di RSUP Prof. Dr. R. D. Kandou Manado.

\section{METODE PENELITIAN}

Jenis penelitian ini ialah deskriptif dengan desain potong lintang. Data diambil melalui kuesioner yang berisikan pernyataan benar-salah yang harus dijawab dengan tepat oleh setiap responden. Sampel penelitian dipilih dengan cara cluster sampling dan menggunakan rumus Slovin sehingga didapatkan 91 responden. Responden diambil dari beberapa ruang rawat inap di RSUP Prof. Dr. R. D. Kandou Manado 


\section{HASIL PENELITIAN}

Responden diambil dari Irina A, Irina $\mathrm{B}$, Irina C, Irina D, Irina E, Irina F (THTNeuro), Irina Anggrek, Irina Nyiur, ruang hemodialisis, ruang Edelweiss, dan Cardiovascular and Brain Center (CVBC). Dari setiap ruangan rawat inap diambil 7-8 responden. Data yang terkumpul berupa data demografi dan data tingkat pengetahuan.

Tabel 1 memperlihatkan bahwa dari 91 responden sebagian besar berusia dewasa awal (21-40 tahun) yaitu sebanyak 75 responden $(82,41 \%)$ sedangkan yang berusia dewasa madya (41-60 tahun) sebanyak 16 responden (17.59\%).

Tabel 1. Distribusi responden menurut usia

\begin{tabular}{lcc}
\hline \multicolumn{1}{c}{ Usia } & Frekuensi & \% \\
\hline Dewasa awal & 75 & 82,41 \\
Dewasa madya & 16 & 17,59 \\
Total & 91 & 100 \\
\hline
\end{tabular}

Tabel 2 memperlihatkan bahwa dari 91 responden terdapat 78 responden perempuan $(85,71 \%)$ dan 13 responden laki-laki $(14,29 \%)$.

Tabel 2. Distribusi responden menurut jenis kelamin

\begin{tabular}{lcc}
\hline \multicolumn{1}{c}{$\begin{array}{c}\text { Jenis } \\
\text { kelamin }\end{array}$} & Frekuensi & \% \\
\hline Laki-laki & 13 & 14,29 \\
Perempuan & 78 & 85,71 \\
Total & 91 & 100 \\
\hline
\end{tabular}

Tabel 3 menyajikan distribusi responden dengan tingkat pendidikan DIII keperawatan sebanyak 20 responden $(21,98 \%)$, responden dengan tingkat pendidikan DIII kebidanan sebanyak 5 responden $(5,5 \%)$, responden dengan tingkat pendidikan DIV kebidanan sebanyak 1 responden $(1,1 \%)$, responden dengan tingkat pendidikan sarjana keperawatan sebanyak 13 responden $(14,28 \%)$, dan responden dengan tingkat pendidikan ners, sebanyak 52 responden $(57,14 \%)$.
Tabel 3. Distribusi responden menurut tingkat pendidikan

\begin{tabular}{lcc}
\hline Pendidikan & Frekuensi & \% \\
\hline DIII & 20 & 21,98 \\
Keperawatan & & \\
DIII Kebidanan & 5 & 5,5 \\
DIV Kebidanan & 1 & 1,1 \\
Sarjana & 13 & 14,28 \\
Keperawatan & & \\
Ners & 52 & 57,14 \\
Total & 91 & 100 \\
\hline
\end{tabular}

Tabel 4 menampilkan bahwa dari 91 responden, jumlah responden yang memiliki masa kerja $<5$ tahun sebanyak 34 orang $(37,36 \%)$, yang memiliki masa kerja 5-10 tahun sebanyak 27 orang $(29,67 \%)$, yang memiliki masa kerja $>10$ tahun sebanyak 30 orang $(32,97 \%)$.

Tabel 4. Distribusi responden menurut masa kerja

\begin{tabular}{lcc}
\hline Masa kerja & Jumlah & \% \\
\hline$<5$ Tahun & 34 & 37,36 \\
5-10 Tahun & 27 & 29,67 \\
$>10$ Tahun & 30 & 32,97 \\
Total & 91 & 100 \\
\hline
\end{tabular}

Data tingkat pengetahuan tenaga paramedis tentang code blue system diperoleh melalui kemampuan responden menjawab dengan tepat pernyataan yang ada pada kuesioner. Setiap pernyataan memiliki peluang skor 0 (jawaban salah/pernyataan tidak sesuai) dan skor 1 (jawaban benar/pernyataan sesuai). Setiap responden dimungkinkan memiliki skor minimal 0 dan maksimal 6. Selanjutnya persentase pernyataan yang dijawab dengan tepat yang diperoleh masing-masing responden dihitung dan diklasifikasikan ke dalam 4 (empat) kategori untuk menentukan tingkat pengeahuannya tentang code blue system, yaitu: kategori tinggi (jawaban tepat 76\%$100 \%$ ); kategori cukup tinggi (jawaban tepat 56\%-75\%); kategori rendah (jawaban tepat 40\%-55\%); dan kategori sangat rendah (jawaban tepat kurang dari 40\%). 
Tabel 5 menunjukkan bahwa sebagian besar responden sebanyak $27(29,67 \%)$ tenaga paramedis mempunyai tingkat pengetahuan tentang code blue system dengan kategori tinggi. Sisanya sebanyak $23(25,28 \%)$ tenaga paramedis dengan kategori cukup tinggi, $24(26,37 \%)$ tenaga paramedis dengan kategori rendah, dan 17 $(18,68 \%)$ tenaga paramedis dengan kategori sangat rendah.

Tabel 6 memperlihatkan bahwa mayoritas responden yang berada pada kategori usia dewasa awal (21-40 tahun) memiliki tingkat pengetahuan tentang code blue system yang tinggi yaitu sebanyak 23 responden $(25,27 \%)$. Responden yang berada pada kategori usia dewasa madya (41-60 tahun) memiliki jumlah responden yang sama pada ke-empat tingkat pengetahuan, yaitu masing-masinmg 4 responden $(4.39 \%)$.

Tingkat pengetahuan tentang code blue system yang tinggi, cukup tinggi, dan rendah terdistribusi secara merata pada responden dengan jenis kelamin laki-laki, yaitu masing-masing sebanyak 4 responden $(4,39 \%)$. Pada responden dengan jenis kelamin perempuan, mayoritas responden memiliki tingkat pengetahuan yang tinggi yaitu sebanyak 23 responden $(25,27 \%)$.

Mayoritas responden dengan tingkat pendidikan DIII keperawatan memiliki tingkat pengetahuan yang rendah tentang code blue system yaitu sebanyak 10 responden $(10,99 \%)$. Mayoritas responden dengan tingkat pendidikan DIII kebidanan memiliki jumlah yang sama, yaitu 2 responden $(2,19 \%)$ berada pada tingkat pengetahuan yang rendah dan cukup tinggi.
Hanya terdapat 1 responden $(1,09 \%)$ dengan tingkat pendidikan DIV kebidanan; responden tersebut memiliki tingkat pengetahuan rendah. Responden dengan tingkat pendidikan sarjana keperawatan memiliki mayoritas tingkat pengetahuan yang rendah pula, yaitu sebanyak 5 responden (5,49\%). Responden dengan tingkat pendidikan ners memiliki mayoritas tingkat pengetahuan tinggi, dengan jumlah 18 responden $(19,78 \%)$.

Mayoritas responden dengan masa kerja $<5$ tahun memiliki tingkat pengetahuan yang tinggi yaitu 11 orang $(12,09 \%)$. Responden dengan masa kerja 5-10 tahun memperlihatkan jumlah responden pada tingkat pengetahuan tinggi dan rendah sama banyak yaitu 8 orang $(8,79 \%)$. Mayoritas responden dengan masa kerja $>10$ tahun memiliki tingkat pengetahuan cukup tinggi yautu 11 orang (12,09\%).

\section{BAHASAN \\ Karakteristik responden}

Berdasarkan usia, mayoritas responden yang berada pada kategori usia dewasa awal (21-40 tahun) memiliki tingkat pengetahuan yang tinggi, yaitu sebanyak 23 responden $(25,27 \%)$. Semakin muda usia individu maka kemampuan mengingat akan semakin tinggi termasuk kemampuan untuk mengingat informasi yang diterima. ${ }^{12}$

Hasil penelitian menunjukkan bahwa 78 dari total 91 responden berjenis kelamin perempuan $(85,71 \%)$. Hal tersebut disebabkan pada setiap ruang rawat inap memiliki tenaga paramedis atau perawat yang berjenis kelamin perempuan lebih banyak dari yang berjenis kelamin laki-laki.

Tabel 5. Distribusi frekuensi tingkat pengetahuan responden tentang code blue system

\begin{tabular}{lccc}
\hline $\begin{array}{c}\text { Kategori tingkat } \\
\text { pengetahuan }\end{array}$ & $\begin{array}{c}\text { Persentase } \\
\text { jawaban benar }\end{array}$ & Frekuensi & Persentase \\
\hline Tinggi & $76-100 \%$ & 27 & 29,67 \\
Cukup tinggi & $56-75 \%$ & 23 & 25,28 \\
Rendah & $40-55 \%$ & 24 & 26,37 \\
Sangat rendah & $<40 \%$ & 17 & 18,68 \\
Jumlah & & 91 & 100 \\
\hline
\end{tabular}


Tabel 6. Tingkat pengetahuan berdasarkan usia, jenis kelamin, tingkat pendidikan dan masa kerja

\begin{tabular}{|c|c|c|c|c|c|c|c|c|c|c|}
\hline \multirow{3}{*}{$\begin{array}{l}\text { Karakteristik } \\
\text { Usia }\end{array}$} & \multicolumn{10}{|c|}{ Tingkat pengetahuan } \\
\hline & \multicolumn{2}{|c|}{$\begin{array}{l}\text { Sangat } \\
\text { rendah }\end{array}$} & \multicolumn{2}{|c|}{ Rendah } & \multicolumn{2}{|c|}{ Cukup tinggi } & \multicolumn{2}{|c|}{ Tinggi } & \multicolumn{2}{|c|}{ Total } \\
\hline & $\mathrm{F}$ & $\%$ & $\mathrm{~F}$ & $\%$ & $\mathrm{~F}$ & $\%$ & $\bar{F}$ & $\%$ & F & $\%$ \\
\hline $\begin{array}{l}\text { Dewasa awal } \\
\text { (21-40 Tahun) }\end{array}$ & 13 & 14,28 & 20 & 21,98 & 19 & 20,88 & 23 & 25,27 & 75 & 82,41 \\
\hline $\begin{array}{l}\text { Dewasa madya } \\
\text { (41-60 Tahun) }\end{array}$ & 4 & 4,39 & 4 & 4,39 & 4 & 4,39 & 4 & 4,39 & 16 & 1,59 \\
\hline \multicolumn{11}{|l|}{ Jenis kelamin } \\
\hline Laki-laki & 1 & 1,09 & 4 & 4,39 & 4 & 4,39 & 4 & 4,39 & 13 & 14,29 \\
\hline Perempuan & 16 & 17,58 & 19 & 20,88 & 19 & 20,88 & 23 & 25,27 & 78 & 85,71 \\
\hline \multicolumn{11}{|l|}{$\begin{array}{l}\text { Tingkat } \\
\text { pendidikan }\end{array}$} \\
\hline DIII Kebidanan & 0 & 0 & 2 & 2,19 & 2 & 2,19 & 1 & 1,09 & 5 & 5,5 \\
\hline DIV Kebidanan & 0 & 0 & 1 & 1,09 & 0 & 0 & 0 & 0 & 1 & 1,09 \\
\hline $\begin{array}{l}\text { Sarjana } \\
\text { Keperawatan }\end{array}$ & 2 & 2,19 & 5 & 5,49 & 3 & 3,29 & 3 & 3,29 & 13 & 14,28 \\
\hline Ners & 12 & 13,18 & 6 & 6,59 & 14 & 15,38 & 18 & 19,78 & 52 & 57,14 \\
\hline \multicolumn{11}{|l|}{ Masa kerja } \\
\hline$<5$ Tahun & 7 & 7,69 & 9 & 9,89 & 7 & 7,69 & 11 & 12,09 & 34 & 37,36 \\
\hline 5-10 Tahun & 6 & 6,59 & 8 & 8,79 & 5 & 5,49 & 8 & 8,79 & 27 & 29,67 \\
\hline$>10$ Tahun & 4 & 4.39 & 7 & 7,69 & 11 & 12,08 & 8 & 8,79 & 30 & 32,97 \\
\hline
\end{tabular}

Ners merupakan mayoritas tingkat pendidikan yang dimiliki dari seluruh responden. Responden dengan tingkat pendidikan Ners mencapai 52 dari 91 responden $(57,14 \%)$. Tingkat pengetahuan yang dimiliki oleh sebagian besar responden dengan tingkat pendidikan Ners lebih tinggi dari tingkat pendidikan yang lainnya. Menurut Notoatmodjo, ${ }^{13}$ orang yang memiliki pengetahuan tinggi akan mempunyai pengetahuan yang lebih luas dibandingkan dengan seseorang yang tingkat pendidikannya lebih rendah. Pernyataan tersebut sejalan dengan hasil penelitian yang diperoleh.

Mayoritas masa kerja responden berada pada rentang <5 tahun sebanyak 34 responden $(37,36 \%)$. Sebagian besar responden dengan masa kerja $<5$ tahun memiliki tingkat pengetahuan yang tinggi tentang code blue system. Distribusi hasil penelitian terkait masa kerja tidak sesuai dengan pernyataan Notoatmodjo ${ }^{13}$ bahwa tingkat pengetahuan dapat berkembang seiring dengan pengalaman yang didapat.

\section{Gambaran tingkat pengetahuan perawat tentang code blue system}

Dari 91 responden sebanyak 27 responden $(29,67 \%)$ memiliki tingkat pengetahuan yang tinggi tentang code blue system (Tabel 6). Responden yang memiliki pengetahuan yang cukup tinggi sebanyak 23 orang $(25,28 \%)$. Responden yang memiliki tingkat pengetahuan yang rendah dan sangat rendah secara berturut-turut ialah 24 orang $(26,37 \%)$ dan 17 orang $(18,68 \%)$.

Berdasarkan pernyataan dalam kuesioner, sebanyak 69 dari 91 responden yang menjawab dengan tidak tepat pada bagian pertanyaan teknis memberikan bantuan hidup dasar. Pernyataan dari soal tersebut tidak sesuai dengan standar prosedur operasional yang diterapkan dalam sistem code blue di rumah sakit sehingga diperlukan edukasi, simulasi, ataupun pelatihan untuk setiap petugas rumah sakit, termasuk perawat

Di RSUP Prof. Dr. R. D Kandou 
belum ada penelitian yang terkait. Namun pada penelitian yang dilakukan oleh Sahin ${ }^{11}$ tentang evaluasi code blue di Rumah Sakit Anak, kejadian code blue dapat teridentifikasi dengan baik setelah meningkatnya pengetahuan yang dimiliki tiap petugas. Oleh karena itu, pengetahuan dan pemahaman tentang code blue system harus dimiliki setiap petugas di rumah sakit, termasuk perawat

\section{Tingkat pengetahuan berdasarkan ka- rakteristik responden}

Tingkat pengetahuan pada setiap individu berbeda satu dengan lainnya; ada yang memiliki tingkat pengetahuan tinggi tetapi ada juga yang memiliki tingkat pengetahuan rendah. Dari 91 responden, sebagian besar memiliki tingkat pengetahuan tinggi, yaitu sebanyak 27 orang $(29,67 \%)$. Pengetahuan merupakan hasil dari tahu, dan ini terjadi setelah orang melakukan pengindraan terhadap suatu objek tertentu. ${ }^{13}$

Menurut Notoatmodjo, ${ }^{13}$ pengetahuan seseorang dapat dipengaruhi oleh beberapa faktor, yaitu: pengalaman, tingkat pendidikan, dan sumber informasi. Mengenai pengalaman, tingkat pengetahuan dapat berkembang seiring dengan pengalaman yang didapatkan. Misalnya, jika seseorang sudah pernah melakukan bantuan hidup dasar, maka ia akan lebih tahu tindakan apa yang harus dilakukan jika ada orang yang memerlukan bantuan hidup dasar. Pendidikan dapat membawa wawasan atau pengetahuan seseorang. Secara umum, orang yang memiliki pengetahuan tinggi akan mempunyai pengetahuan yang lebih luas dibandingkan dengan seseorang yang tingkat pendidikannya lebih rendah. Mengenai sumber informasi, keterpaparan seseorang terhadap informasi memengaruhi tingkat pengetahuannya. Sumber informasi yang dapat memengaruhi pengetahuan tentang code blue system misalnya: edukasi atau pelatihan code blue.

Pada penelitian ini, sebagian besar responden dengan kategori usia dewasa awal (21-40 tahun) yaitu 23 orang $(25,27 \%)$, dengan mayoritas tingkat pendidikan Ners sebanyak 18 orang $(19,78 \%)$ dan masa kerja $<5$ tahun sebanyak 11 orang $(12,09 \%)$ memiliki tingkat pengethuan yang tinggi tentang code blue system. Hal ini selaras dengan pernyataan Juliana et al tentang hubungan usia dengan pengetahuan bahwa semakin muda usia individu maka kemampuan mengingat akan semakin tinggi termasuk kemampuan untuk mengingat informasi yang diterima. ${ }^{12}$ Mayoritas tingkat pendidikan yang dimiliki menggambarkan kesesuaian dari teori Notoatmodjo bahwa orang yang memiliki tingkat pendidikan yang lebih tinggi cenderung memiliki pengetahuan yang lebih luas. Namun, kesesuaian teori Notoatmodjo tidak berlaku untuk masa kerja yang dimiliki responden karena keterpaparan informasi turut memengaruhi tingkat pendidikan.

\section{SIMPULAN}

Berdasarkan hasil penelitian ini dapat disimpulkan bahwa tingkat pengetahuan perawat tentang code blue system di RSUP Prof. Dr. R. D. Kandou Manado sebagian besar berada pada kategori tinggi.

\section{SARAN}

Disarankan untuk penelitian lanjut agar menambahkan pernyataan yang akan digunakan dalam alat ukur kuesioner. Penelitian tentang code blue system di RSUP Prof. Dr. R. D. Kandou dapat dilakukan juga dengan metode yang berbeda. Diharapkan hasil penelitian ini menjadi bahan evaluasi untuk pihak rumah sakit dalam meningkatkan kualitas tenaga paramedis yang bertugas.

\section{DAFTAR PUSTAKA}

1. Graham R, McCoy MA, Schultz AM. Strategies to improve cardiac arrest survival: a time to act. Washington, DC: The National Academies Press, 2015.

2. Mozaffarian D, Benjamin EJ, Go AS, Arnett DK, Blaha MJ, Cushman M, et al; on behalf of the American Heart Association Statistics Committee and Stroke Statistics Subcommittee. Heart disease and stroke statistics-2015 update: a report from the American Heart Association. Circulation. 2015; 131:e29-e322. 
3. Merchant RM, Berg RA, Yang L, Becker LB, Groeneveld PW, Chan PS. Hospital variation in survival after in- hospital cardiac arrest. Journal of the American Heart Association 2014;3. doi:10.1161/jaha.113.000400.

4. Pusponegoro A, et al. Buku Panduan Basic Trauma Life Support (3rd ed). Jakarta: Penerbit Yayasan Ambulans Gawat Darurat 18, 2010.

5. Rondonuwu MR. Rumah Sakit Umum Pusat Prof. Dr. R. D. Kandou Manado. Standar Prosedur Operasional Code Blue. 29 Maret 2017. No. Dokumen: UK.01.10/II.1/30.1/2017

6. American Heart Association about Cardiac Arrest. [cited 2018 Sept 3]. Available from: http://www. heart.org/en/healthtopics/cardiac-arrest/about-cardiacarrest

7. Abubakar M, Suryono B, Sarosa P, et al. Panduan Early Warning Scoring System dan Code Blue System. Yogyakarta: Departemen Anestesiologi dan Terapi Intensif FK UGM-RSUP Dr Sardjito - Perdatin Yogyakarta.
8. Eroglu SE, Onur O, Urgan O, Denizbasi A, Akoglu H. Blue code: Is it a real emergency? World J Emerg Med. 2014;5(1):20-3.

9. Wehbe-Janek H, Lenzmeier CR, Ogden PE, Lambden MP, Sanford P, Herrick J, et al. Nurses' perceptions of simulation-based interprofessional training program for rapid response and code blue events. J Nurs Care Qual 2012; 27:43-50.

10. Shapiro SE, Donaldson NE, Scott MB. Rapid response teams seen through the eyes of the nurse. AJN. 2010;110:2834.

11. Sahin KE. Code blue evaluation in childrens hospital. World J Emerg Med. 2016; 7:208.

12. Hutapea EL. Gambaran tingkat pengetahuan polisi lalu lintas tentang bantuan hidup dasar (BHD) di Kota Depok [Skripsi]. Jakarta: Fakultas Ilmu Keperawatan Universitas Indonesia; 2012.

13. Notoatmodjo S. Pendidikan dan Perilaku Kesehatan. Jakarta: Rineka Cipta, 2003 